Sains Malaysiana 49(2)(2020): 237-248

http://dx.doi.org/10.17576/jsm-2020-4902-02

\title{
Impact of Nitric Oxide Synthase 2 Gene Variant on Risk of Anti-Tuberculosis Drug- Induced Liver Injury in the Malaysian Population \\ (Kesan Variasi Gen Nitrik Oksida Synthase 2 terhadap Risiko Kerosakan Hati Akibat Ubat Anti-Tuberkulosis dalam Populasi Malaysia)
}

\author{
Vishala Sivapalan*, Shamsul Mohd Zain, Shengnan Jin, Sze Ling Chan, Jiajun Liu, Zahurin Mohamed \\ \& ROSMAWATI MOHAMED
}

\begin{abstract}
Liver injury is a great threat associated with anti-tuberculosis (anti-TB) medication. Genetic variations in genes encoding drug-metabolising enzymes further enhance this threat. We aimed to explore genetic contributions by evaluating the impact of single nucleotide polymorphisms (SNPS) within the anti-tuberculosis (AT) metabolism pathway genes and within their respective chromosomes on anti-tuberculosis drug-induced liver injury (AT-DILI). Patients ( $n=$ 90) were recruited and 170 SNPs were genotyped using Illumina array and validated using Sanger Sequencing. The well-studied N-acetyltransferase 2 (NAT2*6) rs 1799930 and cytochrome P450 2E1 (CYP2E1) C1/C1 were not significantly associated with AT-DILI in our cohort but nitric oxide synthase (NOS2A) rs11080344-C was found to be significantly higher in the cases than the controls (OR 2.73, 95\% CI 1.12-6.64, P=0.027). Association studies on all other SNPs within the anti-tuberculosis metabolism pathway genes and within their respective chromosomes also found no significant report. Our study suggests that genetic variation in NOS2A could influence the occurrence of AT-DILI.
\end{abstract}

Keywords: Adverse effect; genetic variations; liver injury; nitric oxide; tuberculosis

ABSTRAK

Kerosakan hati adalah ancaman besar yang dikaitkan dengan pengambilan ubat-ubatan anti-tuberkulosis. Variasi genetik dalam gen yang mengekod enzim yang terlibat dalam metabolisme ubat meningkatkan ancaman tersebut. Tujuan kami adalah untuk mengkaji pengaruh genetik dengan menilai impak polimorfisme nukleotid tunggal (SNPS) di dalam gen-gen yang terlibat dalam laluan metabolisme ubat-ubatan anti-tb dan dalam kromosom masing-masing terhadap kecenderungan kerosakan hati akibat ubat anti-tuberkulosis (AT-DILI). Pesakit (n=90) direkrut dan 170 SNPS digenotip menggunakan tatasusunan Illumina dan disahkan menggunakan penjujukan Sanger. Gen N-asetiltransferase 2 (NAT2*6) rs1799930 dan sitokrom P450 2E1 (CYP2E1) C1/C1 yang dikaji secara meluas tidak mempunyai kaitan signifikan dengan AT-DILI dalam kohort kami tetapi nitrik oksida sintase (NOS2A) rs11080344-C didapati secara signifikannya lebih tinggi dalam subjek kes berbanding dengan subjek kawalan (OR 2.73, 95\% CI 1.12-6.64, P=0.027). Kajian SNPs lain yang terlibat di dalam gen dalam laluan matabolisme ubat-ubatan anti-tuberkulosis dan kromosom masing-masing juga tidak menunjukkan kaitan yang signifikan. Kajian kami mencadangkan bahawa variasi genetik di dalam NOS2A boleh mempengaruhi kejadian AT-DILI.

Kata kunci: Kerosakan hati; kesan buruk; nitrik oksida; tuberkulosis; variasi genetik

\section{INTRODUCTION}

Pharmaceutical drugs on the whole greatly improve patient outcomes and quality of life. Although used as prescribed, they are not without their complications. Anti-tuberculosis medication which is used in the treatment of Mycobacterium tuberculosis is also seen to cause various adverse effects to the human body which can lead to delay in treatment outcome, drug resistance, treatment failure, and a corresponding increase in disease morbidity and mortality (Farazi et al. 2014). Anti-tuberculosis drug- induced liver injury (AT-DILI) is the most common and serious adverse effect associated with anti-tuberculosis medication (Tostmann et al. 2008). The first-line tuberculosis drugs recommended by World Health Organization (WHO) include isoniazid (INH), rifampicin and pyrazinamide which are potentially hepatotoxic (World Health Organization 2010) and are used together with ethambutol. Isoniazid is principally associated with AT-DILI with many reports addressed liver injury when used in combination with isoniazid (Farrell 1994; Kurniawati et al. 2012; Thongraung et al. 2012; Tostmann et al. 2008; Xue et al. 2002).

Genetic risk factors of AT-DILI include genes that are involved in the metabolism of the anti- tuberculosis (antiTB) drugs. Isoniazid is first metabolised to acetylisoniazid via $\mathrm{N}$-acetyltransferase 2 (NAT2), followed by hydrolysis 
to acetylhydrazine (Huang 2014). Cytochrome P450 2E1 (CYP2E1) subsequently oxidizes acetylhydrazine to a hepatotoxic intermediate, some of which can be detoxified by the glutathione S-transferase (GST) enzyme (Huang 2014). Another metabolic pathway that generates toxic intermediates is the direct hydrolysis of INH to hydrazine, a potent hepatotoxin (Huang 2014). A meta-analysis showed that the genotypes NAT2 $\mathrm{mt} / \mathrm{mt}$, CYP $2 E 1 * 1 A / * 1 A$ and glutathione S-transferase enzyme M1 (GSTM1) null/ null are associated with increased risk of AT-DILI (Sun et al. 2008) and these associations are significantly evidenced in the East Asian population (Huang 2014). A Brazilian study later demonstrated that slow acetylation status (NAT2 variant) is the only independent risk factor for AT-DILI involving isoniazid (Teixeira et al. 2011).

Malaysia shares many aspects of the global challenges of tuberculosis (TB)-related health problems, especially in recent years in view of the rising incidence of human immunodeficiency virus (HIV)/TB co-infection and influx of foreign workers from neighbouring countries with high tuberculosis related cases (Ministry of Health Malaysia 2015; Rafiza et al. 2011). Statistics on the incidence of AT-DILI in the Malaysian population is scarce. A retrospective study that was carried out showed the incidence of AT-DILI as recorded by the Hospital Universiti Sains Malaysia, Kelantan, is 9.7\% (Marzuki et al. 2008). Apart from NAT2, the bulk of research on AT-DILI to date presents conflicting results and there are marked differences in pharmacogenetics between various populations. In this study, we investigated the association of SNPs in the antituberculosis drug metabolism pathway genes (Huang 2014) which include $N A T 2$, CYP2E1, superoxide dismutase 2 (SOD2), BTB domain and $\mathrm{CNC}$ homolog 1 (BACH1), and nitric oxide synthase $(N O S 2 A)$ with risk of liver injury in the Malaysian population.

\section{MATERIALS AND METHODS}

\section{ETHICS APPROVAL}

This study was approved by the medical ethics committees for clinical research from the University of Malaya Medical Centre (UMMC) (reference number: 955.11) and the National Medical Research Register (NMRR) (NMMR-13443-15579). A written informed consent was obtained from each subject prior to participation in the study.

\section{SUBJECT RECRUITMENT}

Subjects were recruited from the UMMC and the Institute of Respiratory Medicine (IRM) located in Kuala Lumpur, Malaysia. Both institutions are tertiary referral medical centres which receive patients from most parts of Malaysia irrespective of ethnicity and social backgrounds. Patients were recruited in the TB treatment clinic which is referred to as Directly Observed Treatment Strategy (DOTS) clinic, in the respective hospitals based on the following criteria; diagnosis of TB, taking the first-line anti-TB regimen (isoniazid, rifampicin, pyrazinamide and ethambutol), willing to participate in the study as well as able to give informed consent (signed by patient or surrogate). Patients below 18 years age, have other diseases or terminal illnesses, unwilling to participate in the study or unable to give consent, have abnormal liver function (before starting anti-TB medication), and also patients with HIV and hepatitis B and hepatitis C patients were excluded from this study. Once a potential participant was identified during their first visit to the DOTS, an appointment was arranged 4-8 weeks after the initiation of anti-TB treatment for review and liver function monitoring. During the follow up, participants were assessed for symptoms and signs suggestive of drug-induced liver injury (DILI) and blood was collected for liver function test and pharmacogenetics study.

\section{AT-DILI CRITERIA}

AT-DILI assessment was based on the hepatotoxicity that was developed as stated by the American Thoracic Society (Saukkonen et al. 2006) and adapted from Shang et al. (2011). AT-DILI was specifically diagnosed when there is an increase in serum aspartate aminotransferase (AST) or serum alanine aminotransferase (ALT) that is greater than three times of the upper limit normal (ULN) or an increase in total bilirubin that is greater than two times of the ULN, in the absence of viral hepatitis infections, also excluding the use of potentially hepatotoxic drugs, current or previous alcohol consumption $>10 \mathrm{~g} /$ day and other active liver diseases (Saukkonen et al. 2006; Shang et al. 2011; Ruhl \& Everhart 2005). Tuberculosis patients administered with the standard anti-tuberculosis regimen and did not satisfy the criteria for cases as reviewed by the clinician were categorised as controls.

\section{SELECTION OF SINGLE NUCLEOTIDE POLYMORPHISMS (SNPS)}

A total of 170 SNPs within chromosomes harbouring the anti-tuberculosis drug metabolism pathway genes (Huang 2014), particularly the $\mathrm{N}$-acetyltransferase 2 (NAT2), cytochrome P450 2E1 (CYP2E1), superoxide dismutase 2 (SOD2), BTB domain and CNC homolog 1 (BACH1), and nitric oxide synthase (NOS $2 A$ ), were selected and designed for the Illumina genotyping array.

\section{DATA COLLECTION}

Demographic data collected included race, age, gender, and weight. Information on type of TB, smear type, date of treatment initiation, history of TB-related adverse drug reaction, alcohol history, and hepatitis $\mathrm{B}$ and $\mathrm{C}$ status were recorded. Patients' baseline (before the start of medication) liver function test (LFT) was reviewed from their medical record. LFT results 4-8 weeks after initiation of medication 
was obtained from the respective diagnostic centre of the two hospitals.

\section{DNA ISOLATION}

Blood was separated to red blood cells, buffy coat and plasma via centrifugation. DNA extraction was conducted on the buffy coat using QIAmp DNA Mini kit (QIAGEN, USA). A total volume of $150 \mu$ l DNA was obtained from the extraction and qualitative as well as quantitative estimations were performed using NanoDrop spectrophotometer (Thermo Scientific). Approximately 50 ng of DNA sample was utilised in the genotyping.

\section{GENOTYPING}

Genotyping was done using Illumina HumanOmniExpress-24 beadchip (Illumina, San Diego, CA) in collaboration with Translational Laboratory in Genetic Medicine, A*STAR, Singapore and Genome Institute of Singapore using a total of 90 samples. QC was performed to remove samples with high identity-by-state, discordant sex or call rate $<95 \%$, and SNPs with call rate $<95 \%$, minor allele frequency $<0.05$ or deviation from the Hardy-Weinberg Equilibrium.

\section{STATISTICAL ANALYSIS}

SPSS software v25 (SPSS Inc., Chicago, Illinois) was used to perform the statistical analysis. Normality test (Kolmogorov-Smirnov) was performed to identify the normality of the variables. Odds ratio (OR) and the $P$-values for the investigated SNPs ( $P$-values $\leq 0.05$ were considered to be significant) were obtained using multiple regression. An OR $>1.0$ was deemed as the baseline risk whilst OR $<1.0$ as the baseline risk-lowering. An OR $=1$ was considered as normal. Effective allele frequency (EAF) was calculated based on this formula: $\left[\left(\mathrm{BB}^{*} 2\right)+\mathrm{AB}\right] /$ $[(\mathrm{AA}+\mathrm{AB}+\mathrm{BB}) * 2]$. Unless otherwise stated, all data were presented as mean and standard deviation. The comparison between parameters among subjects was tested using independent $t$-test for normally distributed variables or Mann Whitney U test for skewed variables where appropriate. Count variables were compared using Chi square test

\section{ADDITIONAL VALIDATION OF GENOTYPE CALLS BY SEQUENCING}

Validation was conducted by re-genotyping the significant SNP in a number of subjects, randomly selected from the samples using Sanger sequencing. A total of three cases and three controls genomic DNA representing each genotype group selected was cleaned up, optimized and sequenced.

\section{RESULTS}

A total of 90 tuberculosis patients were recruited for this study as shown in Table 1. Fifteen samples fall under the category of AT-DILI cases and 75 samples were controls made up of patients who were on anti-TB medication but did not develop AT-DILI. The patients with AT-DILI were predominantly Malays (56.6\%), followed by Chinese $(19.3 \%)$, Indians $(14.5 \%)$, and others $(9.6 \%)$. Out of the 75 controls, $60 \%$ were Malays, $16 \%$ Chinese, $13.3 \%$ Indians, and $10.6 \%$ others. Pulmonary TB account for majority of the sample at $72.2 \%$. Smear positive sputum was seen in $66.3 \%$ of the TB patients. There were no significant differences in gender $(P=0.924)$ and age between the two groups $(P=0.541)$, therefore, these variables were not taken into account for the subsequent adjustment. However, we did adjust for race despite the $P$-value is strongly suggesting no difference, partly because we think that the subjects were made up of multiple races.

We analysed the association of the SNPs in the antituberculosis drug metabolism pathway genes that include the well-studied NAT2, CYP2E1, SOD2, BACH1, and NOS2A (Huang 2014). Detailed information on the nine SNPs and their association results were obtained (Table 2). Frequency of effective alleles ranges from $0.10-0.80$ in the overall subjects. The effective allele frequency was higher in the cases compared to the control for NAT2 rs4646267, $N A T 2 * 13$ rs $1041983, N A T 2 * 6$ rs1799930, and NOS2A rs11080344. Despite the difference in the frequency between the groups, statistical significant was not achieved in all SNPs except for NOS $2 A$ rs 11080344 . NOS $2 A$ rs 11080344-C was associated with more than 2.7 fold risk of AT-DILI (adjusted OR 2.73, 95\% CI 1.12-6.64, $P=$ $0.027)$. Nevertheless, we could not analyse the results by race stratification due to small sample size. We also extended our analysis for the remaining 161 SNPs within the selected chromosomes. However, there was no difference in allele frequency between the cases and controls (Supplementary Table 1).

\section{DISCUSSION}

In this study, we designed and genotyped 170 SNPs in our attempt to investigate the risk of AT-DILI. We paid special attention to nine SNPs involved in the anti-tuberculosis drug metabolism pathway genes and previously reported to have a strong association with AT-DILI which include alleles of NAT2, CYP2E1, SOD2, NOS2A, and BACH1 (Huang 2014). We found that NOS2A rs 11080344 was significantly associated with AT-DILI in the Malaysian population with 2.73 times greater risk of developing liver injury.

One of the most widely studied genes that has been commonly linked to AT-DILI is NAT2. Polymorphisms of NAT2 gene has been seen to significantly affect functions by decreasing both enzyme stability and the rate of detoxification of drug metabolites in the liver. Allele variant of NAT2 can appear as either slow acetylator (two slow alleles), intermediate acetylator (1 slow and 1 rapid allele) or rapid acetylator (2 rapid alleles, sometimes referred to as 'fast') (McDonagh et al. 2014). Slow acetylators of NAT2 variants are known to contribute to the development of AT-DILI (Wattanapokayakit et al. 2016). A clinical trial of 
TABLE 1. Demographics and clinical profiles of the subjects

\begin{tabular}{|c|c|c|c|c|}
\hline \multirow[t]{2}{*}{ Severity } & & \multicolumn{2}{|c|}{$n$ or mean $\pm \mathrm{SD}$} & \multirow[t]{2}{*}{$P$ value } \\
\hline & & Case $(n=15)$ & Control $(n=75)$ & \\
\hline Gender & $\mathrm{M}: \mathrm{F}$ & $8: 7$ & $42: 33$ & 0.924 \\
\hline \multirow[t]{4}{*}{ Race } & Malay & 8 & 45 & 0.956 \\
\hline & Chinese & 4 & 12 & \\
\hline & Indian & 1 & 1 & \\
\hline & Others & 2 & 8 & \\
\hline \multirow[t]{3}{*}{ Type of TB } & Pulmonary & 12 & 53 & 0.681 \\
\hline & Ex-РТВ & 3 & 20 & \\
\hline & Both & 0 & 2 & \\
\hline \multirow[t]{2}{*}{ Smear } & Smear +ve & 12 & 45 & 0.240 \\
\hline & Smear-ve & 3 & 30 & \\
\hline Age & & $42.1( \pm 17.5)$ & $39.9( \pm 15.4)$ & 0.541 \\
\hline Weight & $\mathrm{kg}$ & $46.8( \pm 6.63)$ & $54.8( \pm 12.3)$ & 0.059 \\
\hline \multirow[t]{5}{*}{ After } & Total Bil (umol/L) & $58.2( \pm 63.9)$ & $9.4( \pm 4.8)$ & $<0.001$ \\
\hline & $\operatorname{ALP}(\mathrm{IU} / \mathrm{L})$ & $170.2( \pm 135.2)$ & $94.2( \pm 32.2)$ & 0.003 \\
\hline & $\operatorname{ALT}(\mathrm{IU} / \mathrm{L})$ & $266.7( \pm 259.6)$ & $37.6( \pm 34.5)$ & $<0.001$ \\
\hline & AST(IU/L) & $215.3( \pm 142.8)$ & $25.0( \pm 22.7)$ & 0.019 \\
\hline & & $150.0( \pm 146.4)$ & $51.3( \pm 58.1)$ & 0.003 \\
\hline
\end{tabular}

Data are expressed as mean $\pm \mathrm{SD}$.

M, male; F, female; Ex-PTB, extrapulmonary; TB; Total Bil, Total Bilirubin; ALT, alanine aminotransferase; AST, aspartate aminotransferase; ALP, alkaline phosphatase; GGT, gamma-glutamyl transferase; After, LFT level after drug exposure.

$\mathrm{P}$ values were obtained by comparing cases and controls using independent t-test

pharmacogenetics based therapy demonstrated that NAT2 genotype guided administration of isoniazid considerably lowers DILI and early treatment failure in the intensive phase of the 6-month four-drug standard treatment of tuberculosis (Azuma et al. 2013). In this clinical trial, patients who are slow acetylators of NAT2 were given lower dosage of isoniazid as compared to the standard dosage, they showed no presence of DILI and demonstrated good clinical progress in tuberculosis (Azuma et al. 2013). A Taiwanese study showed that diplotype NAT2 $6 A / 7 B$ has nearly 8.8 times greater risk of AT-DILI, and similarly, a Brazilian study showed that slow acetylation of NAT2 * $6 a / 6$ with 5.7 times greater risk of AT-DILI (Vizirianakis 2014). A stratified analysis by ethnicity showed that slow acetylators of NAT2 and its susceptibility to anti-TB druginduced hepatitis (ATDH) is significantly seen in the East Asian, South Asian, Brazilian and Middle Eastern populations but not the Caucasians (Du et al. 2013). In this study, however, we observed no significant association of $N A T 2 * 6 A$ with AT-DILI. This result is in contrast with the Indonesian study (Yuliwulandari et al. 2016). Indonesia being a neighbouring country, is expected to share similar genetic structure with the Malaysian Malays. However, a phylogenetic tree in a study by Deng et al. (2015) showed a relatively different genetic makeup between the Peninsular Malays and Indonesian Malays. We also cannot rule out the admixture of ethnicity within our study population, despite the subjects were mainly Malays (Hatin et al. 2011).
We also failed to replicate a significant finding with polymorphism of CYP2E1 in our population. It has been reported that patients taking isoniazid while bearing the CYP2E1 C1/C1 genotype showed increased CYP $2 E 1$ activity, hence more hepatotoxins as compared to the patients with other CYP2E1 genotype (Huang et al. 2003). A recent meta-analysis of 25 independent studies showed only six studies with homozygous CYP2E1 RsaI/PstI C1/ $C 1$ polymorphism increases the risk of AT-DILI (Wang et al. 2016). This meta-analysis included studies done in the East Asian, Indian, South American, and Caucasian populations. According to the pooled estimate, the CYP2E1 RsaI/PstI C1/C1 polymorphism is strongly associated with AT-DILI only in the East Asian population, and this observation is only agreed when ALT level is twice the ULN (Wang et al. 2016). However, when the criteria for cases is ALT $>3 \times$ ULN, as being adopted by our study, CYP2E1 RsaI/PstI C1/C1 polymorphism showed no significant association (Wang et al. 2016). The metaanalysis suggested that the association of CYP2E1 RsaI/ PstI C1/C1 polymorphism with AT-DILI is only seen in those with mild liver injury (Wang et al. 2016), thus, explains our conflicting result.

$S O D$ on the other hand, plays an important role against oxidative stress. $S O D$ exist in three forms, namely cytoplasmic superoxide dismutase (SOD1), mitochondrial superoxide dismutase 2 (SOD2), and extracellular superoxide dismutase (SOD3). A polymorphism in manganese superoxide dismutase (MnSOD, $S O D)$ from 


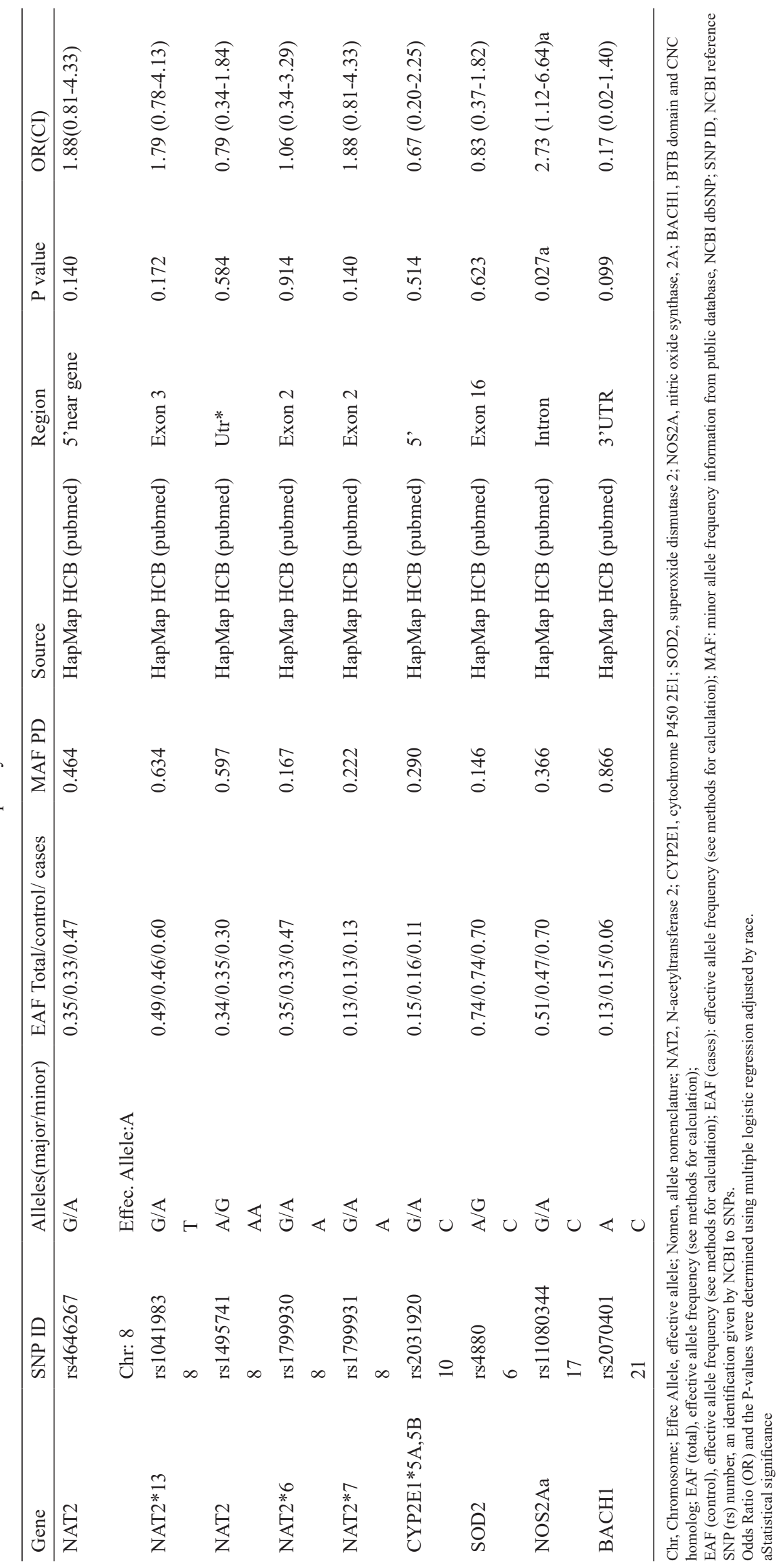


thymine $(\mathrm{T})$ to cytosine $(\mathrm{C})$ demonstrated susceptibility to cancer and alcoholic liver disease (Huang 2014). Patients with variant $\mathrm{C}$ allele of reported $M n S O D$ had a 2.47 times higher risk of developing AT-DILI (Huang 2014). Huang et al. (2007) and Lucena et al. (2010) found that SOD2 polymorphism is associated with AT- DILI in the Taiwanese and Spanish, respectively. On the contrary, the Korean cohort showed that the SOD2 polymorphism is not a risk (Kim et al. 2015). In the present study, our analysis supports the finding from the Korean cohort.

Besides drug metabolizing enzymes, polymorphism in antioxidant enzyme or transcription factors such as nitric oxide synthase (NOS), is seen to link with AT-DILI (Huang 2014). Toxic materials and free radicals are eliminated by the body with the help of antioxidant pathway proteins (Nanashima et al. 2012). Nitric oxide (produced by the inducible form of nitric oxide synthase; iNOS) produces peroxynitrite by reacting with superoxide anion radical 02- (Nanashima et al. 2012). This in turns inactivates antioxidant enzymes by oxidizing thiols and methionine residue causing oxidative stress in hepatocytes (Nanashima et al. 2012). NOS2A rs $11080344 \mathrm{C} / \mathrm{C}$ genotype influences the expression of NOS $2 A$ thus leading to gain-of-function of $i N O S$ activity (Nanashima et al. 2012). NOS2A rs 11080344 is located in the intron region and this polymorphism has the possibility to activate the enhancers and non-coding RNAs or inactivate the repressors that cause a gain of function of iNOS (Nanashima et al. 2012). Mutation in nitric oxide synthase $2 \mathrm{~A}$ (NOS2A) (the inducible form of nitric oxide synthase; $i N O S$ ) produces more nitric oxide, thus, decreasing the function of antioxidant enzymes in the hepatocytes and causes anti-tuberculosis druginduced liver injury (AT-DILI) (Nanashima et al. 2012). To date, there is only one study from the Japanese investigating the association between NOS2A rs11080344 and AT-DILI and the authors showed that $\mathrm{C} / \mathrm{C}$ genotype shows a high risk association with AT-DILI (Nanashima et al. 2012). We confirmed the NOS $2 A$ finding in our population. The association finding of $N O S 2 A$ with AT-DILI in Malaysia suggests its further role in AT-DILI worth to be investigated. In the meantime, the same authors investigated the association between BACH1 rs2070401 and AT-DILI (Nanashima et al. 2012). Similarly, no significant finding was reported (Nanashima et al. 2012). Our result further confirmed the report. Interestingly, the effective allele frequency in our study is similar to the HapMap of the Japanese (0.06) (Zerbino et al. 2017).

One main limitation of this study is the small sample size of AT-DILI patients. Samples were collected at only two hospitals, namely UMMC and IRM. IRM is the referral centre for respiratory diseases and majority of tuberculosis cases from Kuala Lumpur are treated here (Nissapatorn et al. 2007). These two were chosen, as compared to the other hospitals as they were actively involved in monitoring and reporting of AT-DILI cases. Despite low sample size, our study sample size is justifiable. In general, the sample size in pharmacogenetics of AT-DILI ranges from 18-185 for case subjects (Huang et al. 2007, 2002; Kim et al. 2015;
Lucena et al. 2010; Nanashima et al. 2012; Teixeira et al. 2011; Wattanapokayakit et al. 2016; Yuliwulandari et al. 2016). Bigger sample size is often seen in a study adopted the ALT $>2 \times$ ULN in defining the case subject (Huang et al. 2002; Lucena et al. 2010; Wattanapokayakit et al. 2016). It is noteworthy to mention that the study by Nanashima et al. (2012) on NOS2A had a sample size of 18 using the ALT $>2 \times$ ULN criterion. Next, we did not investigate the association by racial breakdown as it will deem a low sample power. Although the incidence and mortality of TB in the country is relatively high (Ministry of Health Malaysia 2018) but there is still under reporting when it comes to AT-DILI cases in the country.

\section{CONCLUSION}

Our study found a significant association of NOS2A and the risk of developing AT-DILI in Malaysia. We suggest that $N O S 2 A$ genetic variant may play a role in disease modification. However, the scale of the NOS $2 A$ rs 11080344 effect warrants a future study in a bigger cohort which is always a dilemma in AT-DILI study. Perhaps, a regional collaboration is necessary to tackle this issue. We hope that these data provide information in the Malaysian setting with regards to genetic of AT-DILI to ensure a better monitoring of AT-DILI in the country.

\section{ACKNOWLEDGEMENTS}

We would like to extend our sincere appreciation to our collaborators at the Translational Laboratory in Genetic Medicine, A*STAR, Singapore as well as the genotyping lab of Genome Institute of Singapore. We also like to thank Dr. Abdul Razak Abdul Muttalif from Institute of Respiratory Medicine (IRM) Kuala Lumpur, Assistant Professor Dr. Liam R Brunham from Translational Laboratory in Genetic Medicine, A*STAR, Singapore and the nurses from both the Directly Observed Treatment Strategy (DOTS) clinics of UMMC and IRM. Financial support was provided by the High Impact Research Grants, University Malaya (UM.C/625/1/HIR/187, J-20001738610) and High Impact Research Grants, Ministry of Higher Education, Malaysia (HIR MOHE E000049-20001). All authors confirm that there is no conflict of interest.

\section{REFERENCES}

Azuma, J., Ohno, M., Kubota, R., Yokota, S., Nagai, T., Tsuyuguchi, K., Okuda, Y., Takashima, T., Kamimura, S., Fujio, Y. \& Kawase, I. 2013. NAT2 genotype guided regimen reduces isoniazid-induced liver injury and early treatment failure in the 6-month four-drug standard treatment of tuberculosis: A randomized controlled trial for pharmacogenetics-based therapy. European Journal of Clinical Pharmacology 69(5): 1091-1101.

Deng, L., Hoh, B.P., Lu, D., Saw, W.Y., Twee-Hee Ong, R., Kasturiratne, A., Janaka de Silva, H., Zilfalil, B.A., Kato, N., Wickremasinghe, A.R., Teo, Y.Y. \& Xu, S. 2015. Dissecting the genetic structure and admixture of four geographical Malay populations. Scientific Reports 5: 14375. 
Du, H., Chen, X., Fang, Y., Yan, O., Xu, H., Li, L., Li, W. \& Huang, W. 2013. Slow N-acetyltransferase 2 genotype contributes to anti-tuberculosis drug-induced hepatotoxicity: A metaanalysis. Molecular Biology Reports 40(5): 3591-3596.

Farazi, A., Sofian, M., Jabbariasl, M. \& Keshavarz, S. 2014. Adverse reactions to antituberculosis drugs in Iranian tuberculosis patients. Tuberculosis Research and Treatment 2014. doi.org/10.1155/2014/412893.

Farrell, G.C. 1994. Drug-Induced Liver Disease. Edinburgh: Churchill Livingstone.

Hatin, W.I., Nur-Shafawati, A.R., Zahri, M.K., Xu, S., Jin, L., Tan, S.G., Rizman-Idid, M. \& Zilfalil, B.A. 2011. Population genetic structure of peninsular Malaysia Malay sub-ethnic groups. PLoS ONE 6(4): e18312.

Huang, Y.S. 2014. Recent progress in genetic variation and risk of antituberculosis drug-induced liver injury. Journal of the Chinese Medical Association 77(4): 169-173.

Huang, Y.S., Su, W.J., Huang, Y.H., Chen, C.Y., Chang, F.Y., Lin, H.C. \& Lee, S.D. 2007. Genetic polymorphisms of manganese superoxide dismutase, NAD (P)H: Quinone oxidoreductase, glutathione S-transferase M1 and T1, and the susceptibility to drug-induced liver injury. Journal of Hepatology 47(1): 128-134.

Huang, Y.S., Chern, H.D., Su, W.J., Wu, J.C., Chang, S.C., Chiang, C.H., Chang, F.Y. \& Lee, S.D. 2003. Cytochrome P450 2E1 genotype and the susceptibility to antituberculosis drug-induced hepatitis. Hepatology 37(4): 924-930.

Huang, Y.S., Chern, H.D., Su, W.J., Wu, J.C., Lai, S.L., Yang, S.Y., Chang, F.Y. \& Lee, S.D. 2002. Polymorphism of the $\mathrm{N}$-acetyltransferase 2 gene as a susceptibility risk factor for antituberculosis drug-induced hepatitis. Hepatology 35(4): 883-889.

Kim, S.H., Kim, S.H., Lee, J.H., Lee, B.H., Yoon, H.J., Shin, D.H., Park, S.S., Jang, S.B., Park, J.S. \& Jee, Y.K. 2015. Superoxide dismutase gene (SOD1, SOD2, and SOD3) polymorphisms and antituberculosis drug-induced hepatitis. Allergy, Asthma \& Immunology Research 7(1): 88-91.

Kurniawati, F., Sulaiman, S.A.S. \& Gillani, S.W. 2012. Adverse drug reactions of primary anti-tuberculosis drugs among tuberculosis patients treated in chest clinic. International Journal of Pharmacy And Life Sciences 3(1): 1331-1338.

Lucena, M.I., Garcia-Martin, E., Andrade, R.J., Martinez, C., Stephens, C., Ruiz, J.D., Ulzurrun, E., Fernandez, M.C., Romero-Gomez, M., Castiella, A., Planas, R., Duran, J.A., De Dios, A.M., Guarner, C., Soriano, G., Borraz, Y. \& Agundez, J.A. 2010. Mitochondrial superoxide dismutase and glutathione peroxidase in idiosyncratic drug-induced liver injury. Hepatology 52(1): 303-312.

Marzuki, O., Fauzi, A., Ayoub, S. \& Kamarul Imran, M. 2008. Prevalence and risk factors of anti-tuberculosis druginduced hepatitis in Malaysia. Singapore Medical Journal 49(9): 688.

McDonagh, E.M., Boukouvala, S., Aklillu, E., Hein, D.W., Altman, R.B. \& Klein, T.E. 2014. PharmGKB summary: Very important pharmacogene information for $\mathrm{N}$-acetyltransferase 2. Pharmacogenetics and Genomics 24(8): 409-425.

Ministry of Health Malaysia. 2015. Global Aids Response Progress Report Malaysia. http:/www.unaids.org/ sites/default/files/country/documents/MYS_narrative_ report_2015.pdf. Accessed on 15 December 2018.

Ministry of Health Malaysia. 2018. Health Facts. http://www. moh.gov.my/resources/index/Penerbitan/Penerbitan $\% 20$
Utama/Fakta\%20kesihatan/KKM_HEALTH_FACTS_2018_ new.pdf. Accessed 6th January 2019.

Nanashima, K., Mawatari, T., Tahara, N., Higuchi, N., Nakaura, A., Inamine, T., Kondo, S., Yanagihara, K., Fukushima, K., Suyama, N., Kohno, S. \& Tsukamoto, K. 2012. Genetic variants in antioxidant pathway: Risk factors for hepatotoxicity in tuberculosis patients. Tuberculosis (Edinburgh, Scotland) 92(3): 253-259.

Nissapatorn, V., Lim, Y.A.L., Jamaiah, I., Man Chin, H., Ilyana, M., Nonaziah, M., Siti Hasifah, A. \& Kuppusamy, I. 2007. Tuberculosis in Malaysia: A continuing surge. Southeast Asian Journal of Tropical Medicine and Public Health 38: 231.

Rafiza, S., Rampal, K.G. \& Tahir, A. 2011. Prevalence and risk factors of latent tuberculosis infection among health care workers in Malaysia. BMC Infectious Diseases 11: 19.

Ruhl, C.E. \& Everhart, J.E. 2005. Joint effects of body weight and alcohol on elevated serum alanine aminotransferase in the United States population. Clinical Gastroenterology and Hepatology 3(12): 1260-1268.

Saukkonen, J.J., Cohn, D.L., Jasmer, R.M., Schenker, S., Jereb, J.A., Nolan, C.M., Peloquin, C.A., Gordin, F.M., Nunes, D., Strader, D.B., Bernardo, J., Venkataramanan, R. \& Sterling, T.R. 2006. An official ATS statement: Hepatotoxicity of antituberculosis therapy. American Journal of Respiratory and Critical Care Medicine 174(8): 935-952.

Shang, P., Xia, Y., Liu, F., Wang, X., Yuan, Y., Hu, D., Tu, D., Chen, Y., Deng, P. \& Cheng, S. 2011. Incidence, clinical features and impact on anti-tuberculosis treatment of antituberculosis drug induced liver injury (ATLI) in China. PLoS ONE 6(7): e21836.

Sun, F., Chen, Y., Xiang, Y. \& Zhan, S. 2008. Drug-metabolising enzyme polymorphisms and predisposition to antituberculosis drug-induced liver injury: A meta-analysis. The International Journal of Tuberculosis and Lung Disease 12(9): 994-1002.

Teixeira, R.L., Morato, R.G., Cabello, P.H., Muniz, L.M., Moreira Ada, S., Kritski, A.L., Mello, F.C., Suffys, P.N., Miranda, A.B. \& Santos, A.R. 2011. Genetic polymorphisms of NAT2, CYP2E1 and GST enzymes and the occurrence of antituberculosis drug-induced hepatitis in Brazilian TB patients. Memorias do Instituto Oswaldo Cruz 106(6): 716724.

Thongraung, W., Lertphongpiroon, W., Pungrassami, P. \& Ratanajamit, C. 2012. Physicians' practices regarding management of antituberculosis drug-induced hepatotoxicity. Southeast Asian Journal of Tropical Medicine and Public Health 43(3): 724-734.

Tostmann, A., Boeree, M.J., Aarnoutse, R.E., de Lange, W.C., van der Ven, A.J. \& Dekhuijzen, R. 2008. Antituberculosis drug-induced hepatotoxicity: Concise up-to-date review. Journal of Gastroenterology and Hepatology 23(2): 192202.

Vizirianakis, I.S. 2014. Handbook of Personalized Medicine: Advances in Nanotechnology, Drug Delivery, and Therapy. 1st ed. Boca Raton: CRC Press.

Wang, F.J., Wang, Y., Niu, T., Lu, W.X., Sandford, A. \& He, J.Q. 2016. Update meta-analysis of the CYP 2E1 RsaI/PstI and DraI polymorphisms and risk of antituberculosis druginduced hepatotoxicity: Evidence from 26 studies. Journal of Clinical Pharmacy and Therapeutics 41(3): 334-340.

Wattanapokayakit, S., Mushiroda, T., Yanai, H., Wichukchinda, N., Chuchottawon, C., Nedsuwan, S., Rojanawiwat, A., Denjanta, S., Kantima, T., Wongyai, J., Suwankesawong, 
W., Rungapiromnan, W., Kidkeukarun, R., Bamrungram, W., Chaiwong, A., Suvichapanich, S., Mahasirimongkol, S. \& Tokunaga, K. 2016. NAT2 slow acetylator associated with anti-tuberculosis drug-induced liver injury in Thai patients. The International Journal of Tuberculosis and Lung Disease: The Official Journal of the International Union against Tuberculosis and Lung Disease 20(10): 1364-1369.

World Health Organization. 2010. Guidelines for Treatment of Tuberculosis. 4th ed. http://www.who.int/tb/ publications/2010/9789241547833/en/. Accessed on 13 August 2018.

Xue, H., Hou, Y. \& Liu, H. 2002. The general investigation of the increased hepatotoxicity caused by isoniazid in combination with rifampin. Chinese Journal Modern Applied Pharmacy 19: 463-465.

Yuliwulandari, R., Susilowati, R.W., Wicaksono, B.D., Viyati, K., Prayuni, K., Razari, I., Kristin, E., Syafrizal, Subagyo, Sri Diana, E., Setiawati, S., Ariyani, A., Mahasirimongkol, S., Yanai, H., Mushiroda, T. \& Tokunaga, K. 2016. NAT2 variants are associated with drug-induced liver injury caused by anti-tuberculosis drugs in Indonesian patients with tuberculosis. Journal of Human Genetics 61(6): 533537.

Zerbino, D.R., Achuthan, P., Akanni, W., Amode, M.R., Barrell, D., Bhai, J., Billis, K., Cummins, C., Gall, A. \& Girón, C.G. 2017. Ensembl 2018. (Ensembl Release 95). Nucleic Acids Research 46(D1): D754-D761.
Vishala Sivapalan* \& Rosmawati Mohamed

Department of Medicine

University of Malaya

50603 Kuala Lumpur, Federal Territory

Malaysia

Shamsul Mohd Zain* \& Zahurin Mohamed

Department of Pharmacology

University of Malaya

50603 Kuala Lumpur, Federal Territory

Malaysia

Shengnan Jin \& Sze Ling Chan

Translational Laboratory in Genetic Medicine (TLGM)

A*Star, 117609

Singapore

Jiajun Liu

Genome Institute of Singapore

A*Star, 60 Biopolis St., 138672

Singapore

*Corresponding author; email: vishalasivapalan87@gmail.com

Received: 4 August 2019

Accepted: 5 December 2019 
SUPPLEMENTARY 1. Analysis of other SNPs on chromosome 8, 10, 6,17, and 21

\begin{tabular}{|c|c|c|c|c|c|}
\hline $\mathrm{Chr}$ & Gene name & SNP ID & Alleles (Major/minor) & P value & $\mathrm{OR}(\mathrm{CI})$ \\
\hline \multirow[t]{46}{*}{8} & NA & rs 13277723 & $\mathrm{~A} / \mathrm{G}$ & 0.50 & $1.34(0.58-3.14)$ \\
\hline & NA & rs 34546534 & $\mathrm{G} / \mathrm{A}$ & 0.43 & $1.70(0.46-6.30)$ \\
\hline & NAT2 & rs7016785 & $\mathrm{A} / \mathrm{G}$ & 0.34 & $0.68(0.31-1.50)$ \\
\hline & NAT2 & rs 7013253 & $\mathrm{~A} / \mathrm{G}$ & 0.55 & $0.78(0.36-1.72)$ \\
\hline & NAT2 & rs10109286 & $\mathrm{A} / \mathrm{G}$ & 1.00 & $1.00(0.43-2.31)$ \\
\hline & NAT2 & rs 10095668 & GG & NIL & NIL \\
\hline & NAT2 & rs4921907 & AA & NIL & NIL \\
\hline & NAT2 & rs7825609 & $\mathrm{AA}$ & NIL & NIL \\
\hline & NAT2 & rs 1565684 & $\mathrm{~A} / \mathrm{G}$ & 0.54 & $1.30(0.56-3.02)$ \\
\hline & NAT2 & rs4646241 & $\mathrm{A} / \mathrm{G}$ & 0.33 & $0.67(0.30-1.50)$ \\
\hline & NAT2 & rs 4646242 & $\mathrm{~A} / \mathrm{G}$ & 0.19 & $0.57(0.25-1.31)$ \\
\hline & NAT2 & rs 4345600 & $\mathrm{~A} / \mathrm{G}$ & 1.00 & $1.00(0.36-2.81)$ \\
\hline & NAT2 & $\mathrm{rs} 4351455$ & GG & NIL & NIL \\
\hline & NAT2 & rs 4271002 & $\mathrm{G} / \mathrm{C}$ & 1.00 & $1.00(0.36-2.81)$ \\
\hline & NAT2 & rs 4646246 & $\mathrm{~A} / \mathrm{G}$ & 0.46 & $1.40(0.56-3.61)$ \\
\hline & NAT2 & rs 11780272 & $\mathrm{~A} / \mathrm{G}$ & 0.41 & $1.72(0.48-6.16)$ \\
\hline & NAT2 & rs 13277605 & $\mathrm{~A} / \mathrm{C}$ & 0.41 & $1.72(0.48-6.16)$ \\
\hline & NAT2 & rs9987109 & $\mathrm{A} / \mathrm{G}$ & 0.36 & $1.81(0.50-6.54)$ \\
\hline & NAT2 & rs2087852 & $\mathrm{A} / \mathrm{G}$ & 0.19 & $0.57(0.25-1.31)$ \\
\hline & NAT2 & rs 2410556 & $\mathrm{AA}$ & NIL & NIL \\
\hline & NAT2 & rs1390358 & $\mathrm{A} / \mathrm{G}$ & 0.45 & $1.72(0.48-6.16)$ \\
\hline & NAT2 & rs 11996129 & $\mathrm{~A} / \mathrm{G}$ & 0.69 & $1.17(0.53-2.57)$ \\
\hline & NAT2 & rs1115784 & $\mathrm{A} / \mathrm{G}$ & 0.69 & $1.17(0.53-2.57)$ \\
\hline & NAT2 & rs1961456 & $\mathrm{A} / \mathrm{G}$ & 0.79 & $1.12(0.51-2.44)$ \\
\hline & NAT2 & rs1112005 & $\mathrm{G} / \mathrm{A}$ & 0.19 & $0.58(0.26-1.3)$ \\
\hline & NAT2 & rs973874 & GG & NIL & NIL \\
\hline & NAT2 & rs7832071 & $\mathrm{G} / \mathrm{A}$ & 0.43 & $0.59(0.16-2.20)$ \\
\hline & NAT2 & rs 1805158 & GG & NIL & NIL \\
\hline & NAT2 & rs1801279 & GG & NIL & NIL \\
\hline & NAT2 & rs 1801280 & $\mathrm{~A} / \mathrm{G}$ & 0.41 & $1.72(0.48-6.16)$ \\
\hline & NAT2 & rs1799929 & $\mathrm{G} / \mathrm{A}$ & 0.46 & $1.63(0.46-5.80)$ \\
\hline & NAT2 & rs4646247 & $\mathrm{G} / \mathrm{A}$ & 0.14 & $1.88(0.82-4.34)$ \\
\hline & NAT2 & rs971473 & $\mathrm{G} / \mathrm{A}$ & 0.80 & $0.86(0.29-2.59)$ \\
\hline & NAT2 & rs721398 & $\mathrm{A} / \mathrm{G}$ & 0.19 & $1.74(0.77-3.97)$ \\
\hline & NAT2 & rs721399 & $\mathrm{G} / \mathrm{A}$ & 0.52 & $1.29(0.60-2.77)$ \\
\hline & NAT2 & rs 11784251 & $\mathrm{~A} / \mathrm{G}$ & 0.52 & $0.77(0.36-1.67)$ \\
\hline & NAT2 & rs4646248 & $\mathrm{G}=\mathrm{A}$ & 0.44 & $1.35(0.63-2.92)$ \\
\hline & NAT2 & rs4646249 & $\mathrm{C}=\mathrm{A}$ & 0.44 & $0.74(0.34-1.60)$ \\
\hline & NAT2 & rs 4646250 & $\mathrm{G}=\mathrm{A}$ & 0.44 & $1.35(0.63-2.92)$ \\
\hline & NA & rs 10089306 & GG & NIL & NIL \\
\hline & NA & rs 10088830 & GG & NIL & NIL \\
\hline & NA & rs1390360 & $\mathrm{A}=\mathrm{G}$ & 0.44 & $1.35(0.63-2.92)$ \\
\hline & NA & rs1908586 & $\mathrm{A}=\mathrm{G}$ & 0.93 & $1.05(0.37-2.95)$ \\
\hline & NA & rs2410557 & $\mathrm{CC}$ & NIL & NIL \\
\hline & NA & rs 1908587 & $\mathrm{~A} / \mathrm{C}$ & 0.93 & $0.96(0.35-2.62)$ \\
\hline & NA & rs4455879 & $\mathrm{CC}$ & NIL & NIL \\
\hline
\end{tabular}




\begin{tabular}{|c|c|c|c|c|c|}
\hline & NA & rs 1495745 & $\mathrm{~A}=\mathrm{C}$ & 0.42 & $1.41(0.61-3.25)$ \\
\hline & NA & rs 1495746 & $\mathrm{~A} / \mathrm{G}$ & 0.42 & $1.41(0.61-3.25)$ \\
\hline & NA & rs 1495747 & $\mathrm{~A}=\mathrm{G}$ & 0.44 & $1.35(0.53-2.92)$ \\
\hline & NA & rs2410558 & $\mathrm{A} / \mathrm{G}$ & 0.52 & $1.29(0.60-2.77)$ \\
\hline & NA & rs4540438 & $\mathrm{A} / \mathrm{C}$ & 0.85 & $0.90(0.30-2.70)$ \\
\hline & NA & rs 12674710 & $\mathrm{~A} / \mathrm{C}$ & 0.72 & $0.85(0.35-2.04)$ \\
\hline & NA & rs10103029 & $\mathrm{A} / \mathrm{G}$ & 0.72 & $0.85(0.35-2.04)$ \\
\hline & NA & rs 10088333 & $\mathrm{G} / \mathrm{A}$ & 0.72 & $0.85(0.35-2.04)$ \\
\hline & NA & rs 12543818 & $\mathrm{~A} / \mathrm{C}$ & 0.60 & $1.20(0.56-2.70)$ \\
\hline & NA & rs 12545528 & $\mathrm{~A} / \mathrm{C}$ & 0.60 & $1.20(0.56-2.70)$ \\
\hline & NA & rs4921911 & $\mathrm{G} / \mathrm{A}$ & 0.45 & $1.37(0.61-3.06)$ \\
\hline & NA & rs4921913 & $\mathrm{G} / \mathrm{A}$ & 0.58 & $1.20(0.55-3.00)$ \\
\hline & NA & rs4921914 & $\mathrm{A} / \mathrm{G}$ & 0.58 & $1.20(0.55-3.00)$ \\
\hline & NA & rs 1495742 & $\mathrm{G} / \mathrm{A}$ & 0.83 & $1.10(0.46-2.53)$ \\
\hline \multirow[t]{34}{*}{10} & LOC107984284 & rs9418988 & $\mathrm{G} / \mathrm{A}$ & 0.13 & $0.53(0.23-1.21)$ \\
\hline & LOC107984284 & rs 10857733 & $\mathrm{G} / \mathrm{A}$ & 0.73 & $0.83(0.29-2.4)$ \\
\hline & LOC107984284 & rs 10776687 & $\mathrm{G} / \mathrm{A}$ & 0.73 & $0.83(0.29-2.4)$ \\
\hline & LOC107984284 & rs 10857735 & $\mathrm{C} / \mathrm{A}$ & 0.13 & $1.82(0.84-3.95)$ \\
\hline & LOC107984285 & rs 10857736 & $\mathrm{~A} / \mathrm{G}$ & 0.13 & $1.82(0.84-3.95)$ \\
\hline & CYP2E1 & rs3813867 & $\mathrm{C} / \mathrm{G}$ & 0.94 & $0.96(0.38-2.46)$ \\
\hline & CYP2E1 & rs2070673 & $\mathrm{T} / \mathrm{A}$ & 0.11 & $1.9(0.86-4.22)$ \\
\hline & CYP2E1 & rs6413420 & $\mathrm{CC}$ & NIL & NIL \\
\hline & CYP2E1 & rs943975 & $\mathrm{G} / \mathrm{A}$ & 0.73 & $1.21(0.42-3.5)$ \\
\hline & CYP2E1 & rs8192771 & $\mathrm{AA}$ & NIL & NIL \\
\hline & CYP2E1 & rs915906 & $\mathrm{A} / \mathrm{G}$ & 0.04 & $0.40(0.16-0.97)$ \\
\hline & CYP2E1 & rs2070674 & $\mathrm{G} / \mathrm{A}$ & 0.73 & $0.83(0.28-2.4)$ \\
\hline & CYP2E1 & rs2070675 & $\mathrm{G} / \mathrm{A}$ & 0.16 & $1.74(0.81-3.73)$ \\
\hline & CYP2E1 & rs9919378 & $\mathrm{CC}$ & NIL & NIL \\
\hline & CYP2E1 & rs6413419 & GG & NIL & NIL \\
\hline & CYP2E1 & rs6413421 & $\mathrm{AA}$ & NIL & NIL \\
\hline & CYP2E1 & rs915907 & $\mathrm{C} / \mathrm{A}$ & 0.14 & $1.77(0.83-3.77)$ \\
\hline & CYP2E1 & rs915908 & $\mathrm{G} / \mathrm{A}$ & 0.67 & $0.78(0.26-2.40)$ \\
\hline & CYP2E1 & rs915909 & GG & NIL & NIL \\
\hline & CYP2E1 & rs8192775 & $\mathrm{G} / \mathrm{A}$ & 0.82 & $1.11(0.46-2.68)$ \\
\hline & CYP2E1 & rs7092584 & $\mathrm{G} / \mathrm{A}$ & 0.13 & $1.82(0.84-3.95)$ \\
\hline & CYP2E1 & rs 743534 & $\mathrm{G} / \mathrm{A}$ & 0.10 & $2.58(0.83-8.07)$ \\
\hline & CYP2E1 & rs 743535 & $\mathrm{G} / \mathrm{A}$ & 0.54 & $1.31(0.55-3.10)$ \\
\hline & CYP2E1 & rs11818144 & $\mathrm{AA}$ & NIL & NIL \\
\hline & CYP2E1 & rs1410897 & $\mathrm{G} / \mathrm{A}$ & 0.08 & $2.78(0.88-8.70)$ \\
\hline & CYP2E1 & rs1329149 & $\mathrm{T} / \mathrm{C}$ & 0.08 & $2.78(0.88-8.70)$ \\
\hline & CYP2E1 & rs2070676 & $\mathrm{G} / \mathrm{C}$ & 0.08 & $2.78(0.88-8.70)$ \\
\hline & CYP2E1 & rs2070677 & $\mathrm{T} / \mathrm{A}$ & 0.08 & $2.78(0.88-8.70)$ \\
\hline & CYP2E1 & rs2515641 & $\mathrm{G} / \mathrm{A}$ & 0.16 & $1.75(0.80-3.85)$ \\
\hline & CYP2E1 & rs2515642 & $\mathrm{G} / \mathrm{A}$ & 0.16 & $0.57(0.26-1.26)$ \\
\hline & CYP2E1 & rs2480259 & $\mathrm{A} / \mathrm{G}$ & 0.18 & $0.58(0.26-1.29)$ \\
\hline & CYP2E1 & rs2480258 & $\mathrm{A} / \mathrm{G}$ & 0.16 & $0.57(0.26-1.26)$ \\
\hline & CYP2E1 & rs2249694 & $\mathrm{A} / \mathrm{G}$ & 0.15 & $0.57(0.26-1.26)$ \\
\hline & CYP2E1 & rs2249695 & $\mathrm{A} / \mathrm{G}$ & 0.15 & $0.57(0.26-1.26)$ \\
\hline
\end{tabular}




\begin{tabular}{|c|c|c|c|c|c|}
\hline & CY2E1 & rs9629960 & $\mathrm{CC}$ & NIL & NIL \\
\hline & CYP2E1 & rs12164704 & $\mathrm{AA}$ & NIL & NIL \\
\hline & CYP2E1 & rs12164799 & GG & NIL & NIL \\
\hline & CYP2E1 & rs 2515644 & $\mathrm{~A} / \mathrm{C}$ & 0.12 & $0.54(0.24-1.19)$ \\
\hline & NA & rs 1952467 & $\mathrm{~A} / \mathrm{G}$ & 0.16 & $0.57(0.26-1.26)$ \\
\hline & NA & rs9629963 & GG & NIL & NIL \\
\hline & NA & rs9629923 & AA & NIL & NIL \\
\hline & NA & rs8192779 & $\mathrm{G} / \mathrm{A}$ & 0.54 & $1.31(0.55-3.10)$ \\
\hline & NA & rs8192781 & $\mathrm{A} / \mathrm{C}$ & 0.16 & $0.57(0.26-1.26)$ \\
\hline & NA & rs9629964 & $\mathrm{CC}$ & NIL & NIL \\
\hline & NA & rs 12266332 & $\mathrm{AA}$ & NIL & NIL \\
\hline & NA & rs9629971 & AA & NIL & NIL \\
\hline & NA & rs 12269057 & $\mathrm{AA}$ & NIL & NIL \\
\hline & NA & rs 1536826 & $\mathrm{~A} / \mathrm{C}$ & 0.12 & $0.54(0.24-1.19)$ \\
\hline & NA & rs 4512750 & $\mathrm{G} / \mathrm{A}$ & 0.16 & $1.75(0.80-3.85)$ \\
\hline & NA & rs9629977 & GG & NIL & NIL \\
\hline & NA & rs11593189 & $\mathrm{A} / \mathrm{G}$ & 0.30 & $1.58(0.66-3.71)$ \\
\hline \multirow[t]{19}{*}{6} & NA & rs 2842985 & $\mathrm{G} / \mathrm{A}$ & 0.56 & $1.27(0.58-2.78)$ \\
\hline & NA & rs9365085 & $\mathrm{G} / \mathrm{A}$ & 0.94 & $1.03(0.44-2.39)$ \\
\hline & NA & rs732498 & $\mathrm{G} / \mathrm{A}$ & 0.78 & $1.13(0.49-2.61)$ \\
\hline & NA & rs6911119 & GG & NIL & NIL \\
\hline & NA & rs 4342445 & $\mathrm{G} / \mathrm{A}$ & 0.94 & $1.03(0.44-2.40)$ \\
\hline & SOD2 & rs5746151 & $\mathrm{G} / \mathrm{A}$ & 0.99 & $3.37 \mathrm{E}+08$ \\
\hline & NA & rs6917589 & $\mathrm{A} / \mathrm{G}$ & 0.94 & $1.03(0.44-2.40)$ \\
\hline & SOD2 & rs5746141 & $\mathrm{G} / \mathrm{A}$ & 0.99 & $3.37 \mathrm{E}+08$ \\
\hline & SOD2 & rs5746142 & GG & NIL & NIL \\
\hline & SOD2 & rs5746140 & $\mathrm{CC}$ & NIL & NIL \\
\hline & SOD2 & rs5746136 & $\mathrm{G} / \mathrm{A}$ & 0.99 & $3.67(0.0)$ \\
\hline & SOD2 & rs5746135 & $\mathrm{G} / \mathrm{A}$ & 1.00 & $3.28 \mathrm{E}+08$ \\
\hline & SOD2 & rs 2758331 & $\mathrm{~A} / \mathrm{C}$ & 0.72 & $0.86(0.38-1.96)$ \\
\hline & SOD2 & rs5746129 & GG & NIL & NIL \\
\hline & SOD2 & rs2855116 & $\mathrm{A} / \mathrm{C}$ & 0.72 & $0.86(0.38-1.96)$ \\
\hline & SOD2 & rs4987023 & GG & NIL & NIL \\
\hline & SOD2 & rs6912979 & $\mathrm{A} / \mathrm{G}$ & 0.69 & $0.85(0.40-1.86)$ \\
\hline & SOD2 & rs5746096 & $\mathrm{CC}$ & NIL & NIL \\
\hline & SOD2 & rs 2758352 & $\mathrm{~A} / \mathrm{G}$ & 0.35 & $1.46(0.67-3.20)$ \\
\hline \multirow[t]{12}{*}{17} & NOS2 & rs 12450521 & $\mathrm{C} / \mathrm{A}$ & 0.88 & $0.94(0.39-2.23)$ \\
\hline & NOS2 & rs944722 & $\mathrm{A} / \mathrm{G}$ & 0.18 & $0.51(0.19-1.38)$ \\
\hline & NOS2 & rs28944201 & GG & NIL & NIL \\
\hline & NOS2 & rs2297516 & $\mathrm{A} / \mathrm{G}$ & 0.18 & $0.58(0.26-1.30)$ \\
\hline & NOS2 & rs28944173 & $\mathrm{A} / \mathrm{G}$ & 0.99 & $3.32 \mathrm{E}+08$ \\
\hline & NOS2 & rs2297518 & $\mathrm{G} / \mathrm{A}$ & 1.00 & $1.00(0.32-3.10)$ \\
\hline & NOS2 & rs9797244 & $\mathrm{A} / \mathrm{G}$ & 1.00 & $1.00(0.32-3.10)$ \\
\hline & NOS2 & rs 3729720 & GG & NIL & NIL \\
\hline & NOS2 & rs3729718 & $\mathrm{AA}$ & NIL & NIL \\
\hline & NOS2 & rs4795067 & $\mathrm{A} / \mathrm{G}$ & 0.20 & $0.51(0.18-1.44)$ \\
\hline & NOS2 & rs3729508 & $\mathrm{A} / \mathrm{G}$ & 0.22 & $0.60(0.27-1.35)$ \\
\hline & NOS2 & rs944725 & $\mathrm{G} / \mathrm{A}$ & 0.81 & $1.12(0.45-2.77)$ \\
\hline
\end{tabular}




\begin{tabular}{cccccc}
\hline NOS2 & rs3730017 & G/A & 0.99 & $3.37 \mathrm{E}+08$ \\
NOS2 & rs3794764 & G/A & 0.78 & $0.85(0.27-2.67)$ \\
NOS2 & rs8072199 & G/A & 0.45 & $0.58(0.14-2.38)$ \\
NOS2 & rs16966563 & G/A & 0.99 & $3.37 \mathrm{E}+08$ \\
NOS2 & rs3794766 & G/A & 0.78 & $0.85(0.27-2.67)$ \\
LINC00189 & rs733610 & $\mathrm{A} / \mathrm{G}$ & 0.11 & $0.50(0.21-1.20)$ \\
BACH1 & $\mathrm{rs} 1153284$ & $\mathrm{~A} / \mathrm{C}$ & 0.20 & $0.42(0.11-1.58)$ \\
BACH1 & $\mathrm{rs} 1153285$ & $\mathrm{G} / \mathrm{A}$ & 0.08 & $2.14(0.90-5.09)$ \\
BACH1 & $\mathrm{rs} 2832283$ & $\mathrm{G} / \mathrm{A}$ & 0.13 & $0.21(0.03-1.61)$ \\
BACH1 & $\mathrm{rs} 1236481$ & $\mathrm{~A} / \mathrm{G}$ & 0.13 & $1.90(0.83-4.34)$ \\
BACH1 & $\mathrm{rs} 7279721$ & $\mathrm{G} / \mathrm{A}$ & 0.17 & $0.27(0.41-1.78)$ \\
BACH1 & $\mathrm{rs} 1153284$ & $\mathrm{~A} / \mathrm{G}$ & 0.20 & $2.38(0.64-9.0)$ \\
BACH1 & $\mathrm{rs} 388707$ & $\mathrm{~A} / \mathrm{G}$ & 0.47 & $0.75(0.34-1.65)$ \\
BACH1 & $\mathrm{rs} 425989$ & $\mathrm{G} / \mathrm{A}$ & 0.47 & $0.75(0.34-1.65)$ \\
BACH1 & $\mathrm{rs} 368322$ & $\mathrm{C} / \mathrm{T}$ & 0.10 & $3.6(0.77-16.80)$ \\
BACH1 & $\mathrm{rs372883}$ & $\mathrm{A} / \mathrm{G}$ & 0.30 & $0.66(0.30-1.46)$ \\
BACH1 & $\mathrm{rs} 15092$ & $\mathrm{G} / \mathrm{A}$ & 0.10 & $3.60(0.77-16.80)$ \\
BACH1 & $\mathrm{rs} 2027605$ & $\mathrm{~A} / \mathrm{G}$ & 0.30 & $0.66(0.30-1.46)$ \\
BACH1 & $\mathrm{rs} 4817283$ & $\mathrm{~A} / \mathrm{G}$ & 0.67 & $0.82(0.34-1.99)$ \\
\hline
\end{tabular}

Chr, Chromosome; NAT2, N-acetyltransferase 2; CYP2E1, cytochrome P450 2E1; SOD2, superoxide dismutase 2; NOS2A, nitric oxide synthase, 2A; BACH1, BTB domain and $\mathrm{CNC}$ homolog;

SNP ID, NCBI reference SNP (rs) number, an identification given by NCBI to SNPs

Odds Ratio (OR) and the P-values were determined using multiple logistic regression adjusted by race 